\title{
Estimating carbon emissions from African wildfires
}

\author{
V. Lehsten ${ }^{1}$, K. Tansey ${ }^{2}$, H. Balzter ${ }^{2}$, K. Thonicke ${ }^{3}$, A. Spessa ${ }^{4}$, U. Weber ${ }^{5}$, B. Smith ${ }^{1}$, and A. Arneth ${ }^{1}$ \\ ${ }^{1}$ Dept. of Physical Geography and Ecosystems Analysis (INES), Geobiosphere Science Centre, Lund University, Sweden \\ ${ }^{2}$ Centre for Environmental Research, Department of Geography, University of Leicester, UK \\ ${ }^{3}$ Potsdam Institute for Climate Impact Research (PIK) e.V., Potsdam, Germany \\ ${ }^{4}$ Walker Institute for Climate System Research, Department of Meteorology, University of Reading, UK \\ ${ }^{5}$ Max-Planck-Institute for Biogeochemistry, Jena, Germany
}

Received: 18 June 2008 - Published in Biogeosciences Discuss.: 8 August 2008

Revised: 28 January 2009 - Accepted: 28 January 2009 - Published: 6 March 2009

\begin{abstract}
We developed a technique for studying seasonal and interannual variation in pyrogenic carbon emissions from Africa using a modelling approach that scales burned area estimates from L3JRC, a map recently generated from remote sensing of burn scars instead of active fires. Carbon fluxes were calculated by the novel fire model SPITFIRE embedded within the dynamic vegetation model framework LPJGUESS, using daily climate input.

For the time period from 2001 to 2005 an average area of $195.5 \pm 24 \times 10^{4} \mathrm{~km}^{2}$ was burned annually, releasing an average of $723 \pm 70 \mathrm{TgC}$ to the atmosphere; these estimates for the biomass burned are within the range of previously published estimates. Despite the fact that the majority of wildfires are ignited by humans, strong relationships between climatic conditions (particularly precipitation), net primary productivity and overall biomass burnt emerged. Our investigation of the relationships between burnt area and carbon emissions and their potential drivers available litter and precipitation revealed uni-modal responses to annual precipitation, with a maximum around $1000 \mathrm{~mm}$ for burned area and emissions, or $1200 \mathrm{~mm}$ for litter availability. Similar response patterns identified in savannahs worldwide point to precipitation as a chief determinant for short-term variation in fire regime. A considerable variability that cannot be explained by fire-precipitation relationships alone indicates the existence of additional factors that must be taken into account.
\end{abstract}

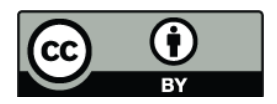

Correspondence to: V. Lehsten (veiko.lehsten@nateko.lu.se)

\section{Introduction}

Fourteen percent of the global population live in Africa, but contribute only 3\% to the total anthropogenic fossil fuel emissions (Williams et al., 2007). However, the role of African ecosystems for the terrestrial carbon cycle and fire emissions is substantial: $20 \%$ of the global net primary production (NPP) and $37 \%$ of carbon emissions by biomass burning have been attributed to the African continent (Williams et al., 2007), the latter being mostly released by savannah fires with ignition patterns dominated by human land-management. The vast majority of all savannah fires globally occur on the African continent (Williams et al., 2007).

For a natural system in steady-state, carbon dioxide released by fire will be re-assimilated by photosynthesis over the ensuing period of re-growth and will not therefore contribute to variation in the global atmospheric $\mathrm{CO}_{2}$ concentration on longer time scales. A different picture emerges, however, when fire is used for the conversion of forests into agricultural land. In this case, much of the carbon combusted from forest woody biomass remains airborne when the burnt land is subsequently used for the cultivation of crops on short rotation cycles. Vegetation wildfires generate a considerable amount of climatically active greenhouse gas and particle emissions on the African continent (Scholes et al., 1996b) but estimates of the seasonal and annual emission patterns are associated with large uncertainties.

The major determinants of the pyrogenic carbon release from wildfires at regional to continental scales are the total available plant material for burning (including litter), the burning conditions that determine the combustion com-

Published by Copernicus Publications on behalf of the European Geosciences Union. 
pleteness, and the annual area burned. Several Africa-wide burned area maps have been produced, e.g. GLOBSCAR (Simon et al., 2004), GBA2000 (Tansey et al., 2004), and the product of Barbosa et al. (1999). However, because of the lack of temporal continuity of these products, burned area estimates required for national greenhouse gas inventories are often based on active fires (dubbed "hotspots") detected using satellite-bound thermal sensors (Giglio et al., 2006; Smith et al., 2007) which are available in near real time. Using active fire detections as a proxy for area burnt in the computation of greenhouse gas emissions has several drawbacks. The detection is limited by cloud cover obscuring the view, as well as by temporal gaps between satellite overpasses. Tansey et al. (2008a) showed that $60 \%$ of burn scars in a degraded peat swamp forest, comprising patches of intact forest in a matrix of secondary vegetation heavily impacted by fire and excessive drainage went undetected by the MODIS thermal anomaly (hotspot) product. In a similar study, Smith et al. (2007) arrived at a hotspot probability detection rate of only $13 \%$ for agricultural fields in Southwestern Australia. The successful detection of an active fire depends on a favourable combination of cloud and smoke free conditions, fire intensity and flame front size prevailing at the exact time that the satellite passes overhead.

An alternative way to map burned areas is to use spectral reflectance data from satellites to detect the presence of burn scars (Tansey et al., 2008b). Because burn scars are much more persistent than the fires that cause them, the available time period for their detection is longer, avoiding many of the above-mentioned problems with active fire detection (Kasischke et al., 2003).

To estimate fire-induced greenhouse gas emissions from the extent of burned area requires knowledge of the total amount and type of biomass burnt and of trace-gas specific emission factors. In the approach presented here, we simulate fire $\mathrm{CO}_{2}$ emissions using a modelling system integrating a detailed mechanistic fire model SPITFIRE (Thonicke et al., 2008) within the dynamic vegetation model LPJ-GUESS (Smith et al., 2001; Sitch et al., 2003), while prescribing burned area based on the global burned area database L3JRC (Tansey et al., 2008b), derived by satellite-based fire scar detection and with a temporal resolution of one day. To our knowledge, the only comparable work which similarly combines satellite-derived fire data with biogeochemical modelling is the GFED data base by van der Werf et al. (2006). The latter is based on burned area estimates from active fire data with the biogeochemistry model CASA providing pyrogenic emission fluxes based on meteorological data, satellitesensed vegetation greenness (Normalised Difference Vegetation Index, NDVI) and prescribed vegetation (vegetation continuous fields ${ }^{1}$ ). Our approach is unique because we use a recent burned area product for Africa in combination with a detailed mechanistic vegetation model that accounts for

\footnotetext{
${ }^{1}$ http://glcf.umiacs.umd.edu/data/vcf/
}

landscape-scale heterogeneity and vertical structure of vegetation, which are important factors determining the burning characteristics as well as fuel loads. The input data to the model are observed, gridded meteorological and soil data. For the period 2001 to 2006 , we investigate the seasonality and inter-annual variation in fire activity and emissions from vegetation fires over the African continent and discuss their relationships to climatic conditions and vegetation productivity.

\section{Materials and methods}

\subsection{Burned area - L3JRC}

The L3JRC burnt area product (Tansey et al., 2008b) covers the period 2001-2006 and is based on SPOT VEGETATION $\mathrm{S} 1$ reflectance data, available on a global, daily, basis. Observations of the ground were restricted to satellite view zenith angles of less than 50.5 degrees and areas of snow, smoke, cloud, cloud shadow and a sun shadow were masked. The burned area algorithm in L3JRC makes use of a temporal index in the $0.83 \mu \mathrm{m}$ (near infrared, NIR) channel that has the advantage of being highly sensitive to the photosynthetic activity of vegetation (see Tansey et al., 2008b for further information). Post-processing of the data serves to utilize the latest land cover information to remove some overdetections believed mainly to be due to the multi-annual detection of leaf-off conditions in temperate regions and lake melt at high northern latitudes. The L3JRC product has been evaluated using 72 Landsat Thematic Mapper (TM) scenes, 14 from the African continent. A comparison between the burnt area detected by L3JRC and that detected by Landsat TM was made between two specified dates. The correlation between burned areas over a standardized equal area grid was computed to derive correlation gradients, intercept values and standard deviations around a best fit line.

The burnt area estimates were corrected for the calculated underestimation of burnt area introduced by the lowresolution observations and also the standard deviation observed around the best-fit line when compared to a number of Landsat TM images. The following assumptions were made: In both hemispheres, approximately $60 \%$ of the burning activity occurs in vegetation that is described in the Global Land Cover (GLC) 2000 product as being broadleaved or deciduous tree or shrub cover of various degrees of openness in reasonably equal portions. The remainder of the burnt area is spread across five other land cover types. From an earlier validation exercise (Tansey et al., 2008b), we know that for tree and shrub cover classes the underestimation of burnt area is approximately $48 \%$ and $35 \%$, respectively. Hence, assuming that on average $60 \%$ of the total area burnt is underestimated by $42 \%$ we can derive a more accurate estimate of the true scale of burning. Furthermore, we corrected for the standard deviation ( 2 s.d.) that we observe in these two 
land cover types which are both close to $8 \%$. No correction was applied to other land cover types, which make up $40 \%$ of the remaining vegetation cover that is burnt. The observed underestimation of over $40 \%$ (Tansey et al., 2008b) informs us that the true scale of burning across Africa is greater than we can easily measure using $1 \mathrm{~km}$ resolution satellite sensors.

\subsection{LPJ-GUESS-SPITFIRE}

To simulate potential vegetation we used the dynamic vegetation modelling framework LPJ-GUESS incorporating the fire model SPITFIRE (Thonicke et al., 2008) as an integral component. LPJ-GUESS, which is described in detail in Smith et al. (2001), simulates potential vegetation as a mixture of plant functional types (PFTs) defined by growth form, phenology, life-history characteristics and bioclimatic limits for establishment and survival. Biogeochemical processes related to assimilation and respiration are similar to a more generalized, global model, LPJ-DGVM (Sitch et al., 2003); the version used in this study includes improved representations of ecosystem hydrological cycling as documented by Gerten et al. (2004). The model framework is applied in "cohort"-mode that represents the vegetation of a given modeled area or gridcell by a number of patches in different stages of recovery or succession following disturbance, and within each patch by cohorts that differ in age and current growth characteristics (Smith et al., 2001). Establishment, mortality and competition among neighboring individuals for light and soil resources are taken into account explicitly. To account for the heterogeneity resulting from population processes, which are modeled stochastically, the vegetation coverage of a grid-cell is taken as the average among the replicated patches (Smith et al., 2001). The model is driven by atmospheric $\mathrm{CO}_{2}$ concentration, temperature, precipitation, radiation, and soil physical properties. For this study, burned area as detected by L3JRC was also prescribed. The burned area map of L3JRC has an original grid spacing of $1 \mathrm{~km}$ and was converted to daily burned fractions per 1 degree grid cell, the latter corresponding to the spatial resolution of the climate input data (see Model experimental setup below). The model runs on a daily time step.

Fuel combustion in SPITFIRE depends on the amount of fuel, the relative proportions of fuels in different size classes (leaves and twigs, small branches, large branches and trunks) and the moisture content of fuels, and follows Peterson and Ryan (1986). The calculation of the latter is based on the Nesterov index (Nesterov, 1949) which accumulates on each consecutive day with precipitation below $3 \mathrm{~mm}$ and is reset to zero (representing saturating litter moisture) after a $3 \mathrm{~mm}$ precipitation event. Following previously used approximations (Venevsky et al., 2002; Thonicke et al., 2008), we set the dew point temperature which is required to calculate the Nesterov Index to the daily minimum temperature minus $4 \mathrm{~K}$ (Running et al., 1987). Since the burned area was prescribed from a burned area product rather than fire hot spots, the ex- act timing of the fire was unknown; it could have occurred any time between last non-detection and first detection of the burn scar which may be separated by a lag of several days. This opens the possibility that burn scars detected for the first time on rainy days might reset the Nesterov Index in the SPITFIRE calculations leading to an underestimation of fire risk. To avoid this problem, we calculated scorch height and fuel combustion from the maximum Nesterov Index of the week preceding the detection of the burn scar.

Fire intensity in SPITFIRE is explicitly simulated as the product of the calorific content of the fuel, the amount of fuel consumed and the rate of spread of the fire front (based on Byram, 1959; Rothermel, 1972; Wilson, 1982; Pyne et al., 1996). It depends on climatic conditions as well as on the type and amount of available fuel produced by the vegetation (Thonicke et al., 2008). Above-ground wood litter simulated in LPJ-GUESS-SPITFIRE was separated into different size classes (leaves and twigs, small branches, large branches and trunks) as constant ratios from the total wood litter mass (comprising mass fractions of 0.045, 0.075, 0.21 and 0.67 , respectively; Thonicke et al., 2008). The classes are distinguished in the rate at which the moisture content equilibrates to prevailing atmospheric moisture, which depends on the surface-area-to-volume ratio of different sized fuel (Pyne et al., 1996). For instance, tree and grass leaf litter has a large surface-area-to-volume ratio, thus equilibrating relatively quickly to changing prevailing atmospheric moisture conditions and supporting intense fires of short duration. Due to their rapid drying response to higher temperatures and/or lower relative humidity, fine fuels are generally totally consumed by most fires and fine fuel fires spread very quickly. By contrast, the fuel classes representing dead stem wood respond less rapidly to changes in ambient moisture conditions because they have a smaller surface-area-tovolume ratio. While coarse litter does not normally affect the rate of spread of fires, when conditions are sufficiently dry, such as during the late dry season or during droughts, coarser fractions become increasingly available for combustion and, as a result, play an increasing role in determining the fire intensity and rate of spread.

Carbon pools are updated annually, in the standard implementation of LPJ-GUESS (Smith et al., 2001). In the case of litter production, however, this would be too coarse to capture the seasonality of the fire regime. Litter carbon pools were therefore updated daily, with raingreen trees shedding their leaves when the ratio of soil water supply to plant demand ( $\omega$; Sitch et al., 2003) fell below 0.35 for more than 30 consecutive days. For grasses, a threshold of 7 days was used. Shed leaves were immediately added to the litter pool. The litter decomposition was separated between wood and leaf litter with turnover times at $10^{\circ} \mathrm{C}$ of 2.85 years for leaf litter and 20 years for wood litter (turnover times decline with temperature following a modified Arrhenius relationship; Sitch et al., 2003). 
All calculations in the SPITFIRE module were based on the daily litter pools as simulated by LPJ-GUESS. Carbon emissions from fires were calculated by multiplying the burned area with the amount of available litter encompassed by it, with the overall combustion depending on the litter type and environmental conditions as described above.

Hanan et al. (2008) identified size dependent mortality as one of the key factors for correctly modelling the effects of wildfires on savannah vegetation. In SPITFIRE, the effect of fires on tree survival depends on the degree of crown and cambial damage (Thonicke et al., 2008). The proportion of the crown affected by fire depends on crown architecture, the height of the tree in relation to the scorch height of the fire, and the resistance to crown scorching, which differs among PFTs. Scorch height is a non-linear function of fire intensity and is likewise PFT-specific. Cambial damage depends on the residence time of the fire and bark thickness, which is a function of tree diameter and is also PFT-specific (Thonicke et al., 2008). This captures the generally observed fireinduced mortality dynamics whereby small trees (i.e. young age cohorts) are more likely to be affected by crown scorching and cambial damage than older and taller trees. During the course of a simulation, this size dependent mortality affects the ratio of trees to grass, the age distribution of trees, feeding back on fuel production and fire intensity.

In order to improve the representation of savannah vegetation dynamics in LPJ-GUESS, a minimum available soil moisture level for tree establishment was introduced, following Miller et al. (2008). By increasing the ratio between stem diameter and tree height for tropical broad-leafed rain-green trees (values based on measurements of Acacia senegal in Demokeya, Sudan, Bashir Awad El Tahir, unpublished) a more realistic tree density was achieved. Fire-related PFT parameters, like susceptibility to crown scorching or cambial damage and fuel bulk density, were generally set as in Thonicke et al. (2008). For tropical broadleaf rain-green trees, however, the mortality in response to complete crown scorching was increased from 5\% to $87 \%$ corresponding to the average stem mortality found for deciduous trees after an intense fire by Williams et al. (1998). Furthermore, the mortality caused by cambial damage was reduced to zero since it is known that these trees suffer very low fire related mortality as long as their crown is not scorched (Hanan et al., 2008). We are not aware of measurements of fuel bulk densities of litter generated by tropical raingreen trees and therefore adopted the value for the tropical broad leafed evergreen trees from Thonicke et al. (2008), which is based on Williams et al. (1998).

\subsection{Model experiment setup}

LPJ-GUESS-SPITFIRE was applied on a $1 \times 1$ degree grid across Africa. 100 patches of $1000 \mathrm{~m}^{2}$ each were simulated for each gridcell, to account for stochastic processes (see Sect. 2.2). The scale at which fires normally occur is larger than the scale of a single simulated patch, and the fractional area burned each year, as detected by L3JRC, can be assumed to be equal to the probability with which any particular patch burns. By simulating multiple patches at each grid cell and subsequently averaging, we ensure not only that the concept of "area burned" within SPITFIRE closely corresponds to the burned area detected by L3JRC but also that effects on vegetation structure, like tree age and spacing are represented realistically (see Fig. 1).

The climate data set covered the period from 1979 to 2006, hereinafter referred to as the "target period". Temperature and global radiation were obtained from NCEP re-analysis II data (Kalnay, 1996) and averaged to daily values. Precipitation was derived by adjusting NCEP re-analysis II data with CRU data (CRU-TS2.1, Mitchell and Jones 2005, extending to 2002 and augmented with data for the year 2003 derived using the same techniques) and TRMM data (Kummerow et al., 1998), in order to correct the known bias in the NCEP precipitation data for this area. The adjustments were carried out as follows. For the TRMM period (1998-2006), a monthly correction factor between NCEP re-analysis II data and TRMM data was applied. For the period prior to TRMM (1979-1997) precipitation was corrected based on the product of a monthly correction factor between CRU data with NCEP re-analysis II data, and a monthly mean correction factor between TRMM data and CRU data (1998-2003). This decreased overall precipitation by $15 \%$. The simulations started with a spin up of 1000 years to achieve vegetation structure and soil carbon pools in approximate steady state with climate at the beginning of the target period. During the spin up, the model was driven by the 28 -year climate time series for the target period, cycled repeatedly, while the $\mathrm{CO}_{2}$ level was kept constant at the 1982 level of $341.13 \mathrm{ppm}$, which is the level stipulated in the CarboAfrica Model Intercomparison protocol (Weber et al., 2008). Following the spin up, $\mathrm{CO}_{2}$ concentrations were set to the observed level for the corresponding calendar year according to measurements at Mauna $\mathrm{Loa}^{2}$. From the target period simulation, output data from the six-year period 2001-2006 were extracted for further analysis.

2.4 Analysis of the relationships between precipitation, burned area, litter and emissions

Since the fire season is shifted by six months between Northern (NHA) and Southern Hemisphere Africa (SHA), we related burned area, emissions and litter to the precipitation which occurred in the 365 days before the average fire season peaking date for the region (NHA: 15 March; SHA: 15 September).

For each grid cell, the arithmetic mean of the precipitation, and the model output variables leaf litter, emissions and burned area were calculated over the six-year period 2001-

\footnotetext{
${ }^{2}$ Data from www.esrl.noaa.gov/gmd/ccgg/trends/.
} 


\section{Burning of simulated cells in LPJ-GUESS-SPITFIRE}

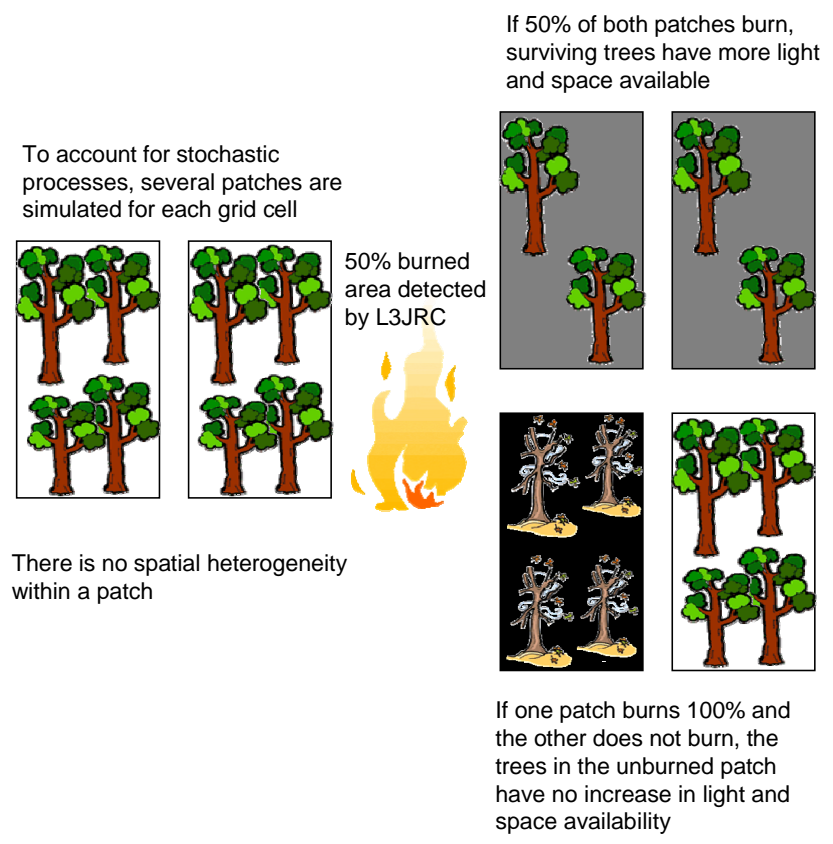

Fig. 1. The representation of burning a fraction of a grid cell in LPJGUESS-SPITFIRE using an example $50 \%$ burned area detected by L3JRC.

2006. A scatter plot was generated and a generalized linear model (GLM) was fitted between the independent and the response variable, applying a logit transformation to the response data and assuming binomial error structures. The logit transformation requires the dependent variable to be bounded between 0 and 1 (Dobson, 2002), which is the case for ratios like the burned area. In the case of leaf area and emissions, which are not ratios, the values were transformed to proportions of an arbitrary maximum value by dividing by $10 \mathrm{~kg}$ for leaf litter and $1 \mathrm{~kg}$ for emissions (see Fig. 6). The (logit) transformation of the response variable $V$ is:

$\operatorname{logit}(V)=\log _{e}(V /(1-V))$.

Values of $V$ which were equal to 0 were set to 0.00001 . The GLMs contained a linear and a quadratic term of the predictor variable. The coefficient of determination $\left(r^{2}\right)$ was calculated by back-transforming the modelled values

$V=1 /\left(1+e^{\operatorname{logit}}(V)\right)$

for the data which were used to estimate the GLM, and regressing them on the observed values. Parameters for the GLMs were derived according to Dobson (2002). Fitting GLMs to the data (i) allows the general trend as well as the shape of the relationship to be examined, which would otherwise be difficult given the limited number of data points in the scatter plot, and (ii) allows a coefficient of determination $\left(r^{2}\right)$ to be computed, showing the strength of the relationship.

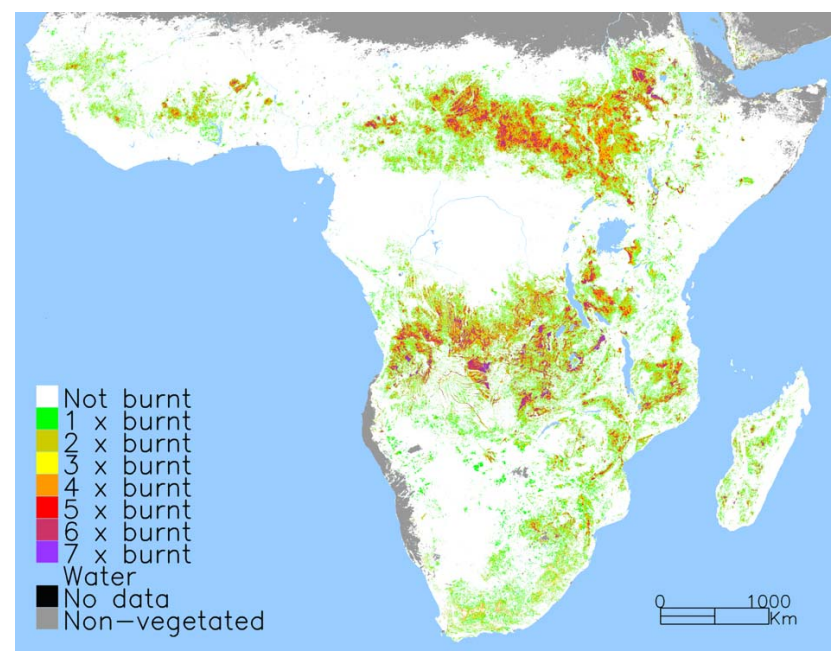

Fig. 2. Frequency and spatial extent of burned area covering the seven year period 1 April 2000-31 March 2007 in sub-Saharan Africa according to the satellite-based burnt area map L3JRC.

\section{Results}

\subsection{Burned area - L3JRC}

The frequency and spatial extent of L3JRC burnt area within the sub-Sahara region of Africa is shown in Fig. 2, covering seven fire years between 1 April 2000 and 31 March 2007. Two main regions of burning activity can be identified where fires occur on an almost annual basis. The first is a region in Sudan, Chad and Ethiopia, the second covers parts of D.R. Congo, Angola, Tanzania and Mozambique. The potential vegetation simulated by LPJ-GUESS-SPITFIRE for these areas mainly consists of drought-deciduous forests and woodlands (not shown, Lehsten et al., 2009). The productivity in these areas is strongly related to precipitation: an increase in precipitation results in a replacement of the deciduous vegetation by evergreen forest according to the model (not shown, Lehsten et al., 2009). Large parts of these areas are used for agriculture and grazing resulting in a high potential for ignition by humans.

Estimates of burnt area, productivity and pyrogenic carbon release are given for the area north and south of the equator in Table 1, separated into the six years covered by L3JRC, and are compared to a number of previously published such estimates.

\subsection{Fire seasonality and pyrogenic carbon emissions}

The fire season of the Northern Hemisphere peaks in March, with very low fire activities from June to January, while in the southern part of the continent the peak lies in October with the main activity from August to January (see Fig. 3).

The calculated total amount of biomass burned for the entire continent was $723 \pm 70 \mathrm{Tg} \mathrm{Ca}^{-1}$ over the period 
Table 1. Burned area, pyrogenic carbon release, net primary production (NPP) and precipitation from this study and other studies mentioned in the text given as annual totals and mean \pm standard deviation where applicable. SHA=Southern Hemisphere Africa, NHA=Northern Hemisphere Africa.

\begin{tabular}{|c|c|c|c|c|c|c|c|c|c|c|c|}
\hline \multirow[b]{2}{*}{ Year } & \multirow[b]{2}{*}{ Area } & \multicolumn{7}{|c|}{ This study } & \multirow{2}{*}{$\begin{array}{l}\text { Van der Werf } \\
\text { et al. (2006) } \\
1997-2004\end{array}$} & \multirow{2}{*}{$\begin{array}{l}\text { Scholes et } \\
\text { al. (1996a) }\end{array}$} & \multirow{2}{*}{$\begin{array}{l}\text { Roberts et } \\
\text { al. (2008) }\end{array}$} \\
\hline & & 2001 & 2002 & 2003 & 2004 & 2005 & 2006 & 2001-2006 & & & \\
\hline \multirow{3}{*}{$\begin{array}{l}\text { Burned area } \\
\left(10^{4} \mathrm{~km}^{2}\right)\end{array}$} & SHA & 136.1 & 98.6 & 113.9 & 98.7 & 91.4 & 112.5 & $108.5 \pm 16.0$ & \multirow{3}{*}{\multicolumn{2}{|c|}{$\begin{array}{l}79.3 \pm 9.6 \\
142.5 \pm 12\end{array}$}} & 75 \\
\hline & NHA & 97.0 & 81.8 & 73.5 & 94.6 & 73.7 & 100.6 & $86.9 \pm 12.0$ & & & 129 \\
\hline & Total & 233.2 & 180.4 & 187.5 & 193.3 & 165.2 & 213.2 & $195.5 \pm 24.3$ & & & 220 \\
\hline \multirow{3}{*}{$\begin{array}{l}\text { Carbon release } \\
\left(\mathrm{Tg} \mathrm{a}^{-1}\right)\end{array}$} & SHA & 580 & 387 & 482 & 379 & 453 & 413 & $448 \pm 75$ & \multirow{3}{*}{$\begin{array}{l}576 \pm 72 \\
627 \pm 75\end{array}$} & \multirow[t]{3}{*}{$45-132$} & \\
\hline & NHA & 277 & 263 & 240 & 339 & 239 & 288 & $274 \pm 37$ & & & 207 \\
\hline & Total & 857 & 650 & 722 & 718 & 691 & 701 & $723 \pm 70$ & & & 427 \\
\hline \multirow{3}{*}{$\begin{array}{l}\text { NPP savannah, deciduous } \\
\text { and xeric forest } \\
\left(\mathrm{PgC}^{-1}\right)\end{array}$} & SHA & 4.1 & 4.0 & 3.7 & 4.0 & 3.4 & 4.3 & $3.9 \pm 0.32$ & \multirow{4}{*}{13} & & \\
\hline & NHA & 2.3 & 2.3 & 2.4 & 2.6 & 2.2 & 2.5 & $2.4 \pm 0.15$ & & & \\
\hline & Total & 9.1 & 8.9 & 8.7 & 9.4 & 7.9 & 10.0 & $9.0 \pm 0.7$ & & & \\
\hline $\begin{array}{l}\text { Total precipitation } \\
\left(10^{4} \mathrm{~km}^{3}\right)\end{array}$ & Total & 1.80 & 1.83 & 1.81 & 1.81 & 1.55 & 1.94 & $1.79 \pm 0.13$ & & & \\
\hline
\end{tabular}

2001-2006 (612 $\pm 40 \mathrm{Tg} \mathrm{Ca}^{-1}$ prior to the correction of burned area by vegetation class from the GLC2000 product) (Table 1). Given the ecosystem model estimate of continental NPP of $9.0 \pm 0.7 \mathrm{Pg} \mathrm{Ca}^{-1}$, more than $8 \%$ of biomass produced annually is consumed by wildfires. Areas with the highest NPP, $1 \mathrm{~kg} \mathrm{C} \mathrm{m}^{-2} \mathrm{a}^{-1}$ or more (Fig. 4), were located in the rain forest region around the equator that contributes only a very small proportion to the fire emissions (Fig. 5). Restricting the analysis to savannah, deciduous and xeric forest ecosystems, defined as areas with a leaf area index (LAI) of tropical rain-green trees above 0.5 following Hickler et al. (2006), some $10 \%$ of NPP is consumed by wildfires annually (savannah $\mathrm{NPP}=7.2 \pm 0.62 \mathrm{Pg} \mathrm{C} \mathrm{a}^{-1}$; emitted carbon $\left.=719 \pm 70 \mathrm{Tg} \mathrm{Ca}^{-1}\right)$.

While the total burned area differed by approximately $20 \%$ between SHA and NHA, the calculated carbon emissions in SHA exceeded emissions in NHA by up to $40 \%$ (Table 1, Fig. 5). Naturally, fire emissions in Northern Africa are constrained by the extensive Sahara desert and Fig. 5 also reveals areas with high emissions in the SHA.

\subsection{Inter-annual variation}

Total burned area varied between simulation years by $33 \%$ whereas the pyrogenic emissions differed by $24 \%$, or $32 \%$ (not shown) for savannahs, deciduous and xeric forests only (Table 1). This variability is higher than the inter-annual range for precipitation (20\%), and also for total (21\%) and savannah, deciduous and xeric forest (17\%) NPP. As expected, annual precipitation was well correlated with NPP $\left(r^{2}=0.91 ; n=6\right.$, Table 1$)$ with highest NPP in the wettest (2006) and lowest NPP in the driest year (2005). Although the magnitude of the inter-annual variation was different for area burnt vs. precipitation and NPP, the year to year varia- tion in simulated emissions follows approximately the variation in burned area in both hemispheres $\left(r^{2}\right.$ values: SHA 0.81 ; NHA 0.75 ; total $0.79 ; n=6$; Table 1$)$.

3.4 Relationships between precipitation, litter, burned area and emissions

Precipitation and burned area showed a non-linear, unimodal relationship, with highest burned area values located in regions with approximately $1000 \mathrm{~mm}$ annual precipitation (Fig. 6a). A similar pattern was detected in the relationship between precipitation and annual fire emissions (Fig. 6b), while for precipitation and available litter, the highest litter production was shifted to slightly higher precipitation (Fig. 6c).

In contrast to relationships with annual precipitation, the highest annual emissions tended to be associated with grid cells which burn each year with a spatial coverage of approximately $40 \%$ (Fig. 6d). Areas with lower, but also with higher, burning frequency exhibited lower annual emissions. Grid cells with high burned area tend to have only low litter accumulation compared to cells with less extensive fires (Fig. 6f).

It is apparent in Fig. 6e that the vegetation in some areas may produce less leaf litter produced in a year than is emitted in fires, although on average (the red line of the modelled response) the emission is lower than the leaf litter. Although green biomass and standing dead wood also contribute to emissions, this apparent discrepancy mainly reflects the influence of litter decomposition, which reduces the reported litter pool in the output of the model.

The fitted GLM parameter values as well as the coefficients of determination $\left(r^{2}\right)$ for each relationship are given in the caption of Fig. 6 . The highest co- 


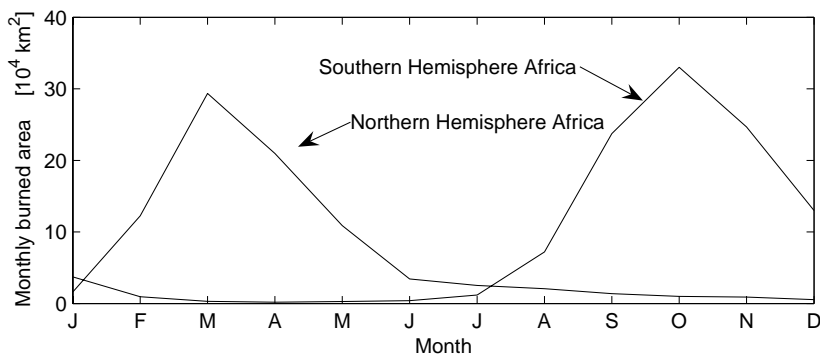

Fig. 3. Seasonality of burned area for Northern and Southern Hemisphere Africa as estimated by L3JRC (mean values for 2001-2006). The total amount of burned area in the southern part of the continent exceeds the burnt area in the northern part by ca. $20 \%$.

efficient of determination was found between burned area and emissions $\left(r^{2}=0.66\right)$ followed by precipitation and litter $\left(r^{2}=0.63\right)$. A combined GLM in which burned area and litter are used as predictors for annual emissions results in $r^{2}=0.75(\operatorname{logit}(\mathrm{E})=-6.5+14.7 \times \mathrm{BA}$ $\left.-15.7 \times \mathrm{BA}^{2}+156 \times \mathrm{Lit} / 10-2314 \times(\mathrm{Lit} / 10)^{2}\right) \quad$ (not plotted). While the coefficient of determination expresses how closely the data points follow the estimated function, P-values of GLMs indicate the difference of each fitted parameter from zero. For each panel in Fig. 6, P-values were found to be below $10^{-10}$ thus indicating the appropriateness of using the GLM for our analysis. Still, the values of $r^{2}$ show that a considerable proportion of variation remains, that cannot be explained by climate and ecosystem response alone but may require more sophisticated models incorporating socio-economic data, such as on land use, human populations and so on (Archibald et al., 2009). Moreover, when interpreting the coefficients of determination, potential crosscorrelations should be considered. For instance, litter production is shown to depend on precipitation (Fig. 6c) while the emissions are also related to precipitation (Fig. 6b), hence the coefficient of determination between litter and emission (Fig. 6e) may be cross-correlated, which has to be taken into account when applying more than one of these relationships, for example as components of a predictive model.

Generating similar GLMs with classes other than leaf litter or with total litter resulted in lower $r^{2}$ (data not shown), indicating that leaf litter had the strongest influence on emissions in the simulations.

\section{Discussion}

We used a remote sensing product to prescribe burnt area in a detailed vegetation model incorporating a mechanistic fire model and used it to investigate climate-vegetation interactions, particularly in terms of NPP and litter production, on fire carbon emissions in Africa. The annual estimates obtained for pyrogenic emissions are well within the range of 300 to $1800 \mathrm{Tg} \mathrm{Ca}^{-1}$ for Africa as a whole (Williams et al.,
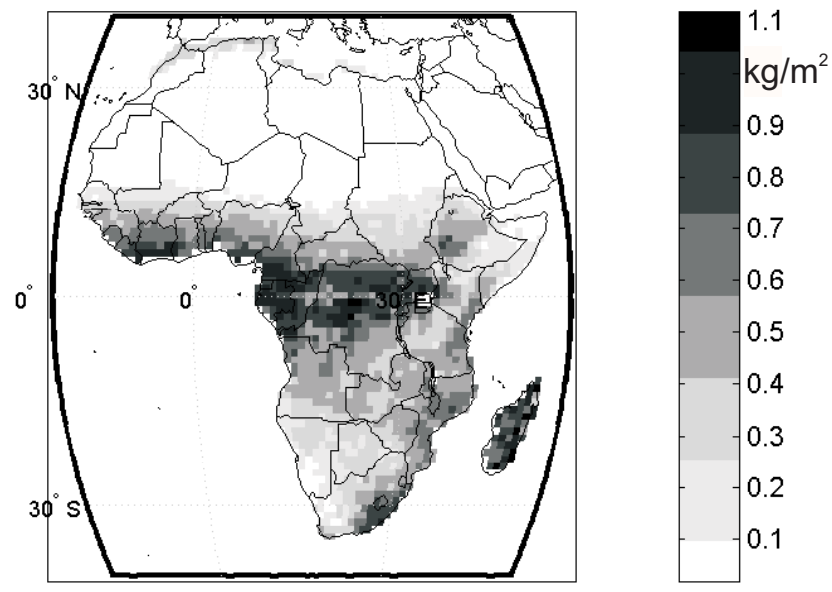

Fig. 4. Average annual net primary production (NPP) in $\mathrm{kg} \mathrm{C} \mathrm{m}^{-2} \mathrm{a}^{-1}$ for the period 2001 to 2006 simulated by LPJGUESS-SPITFIRE.
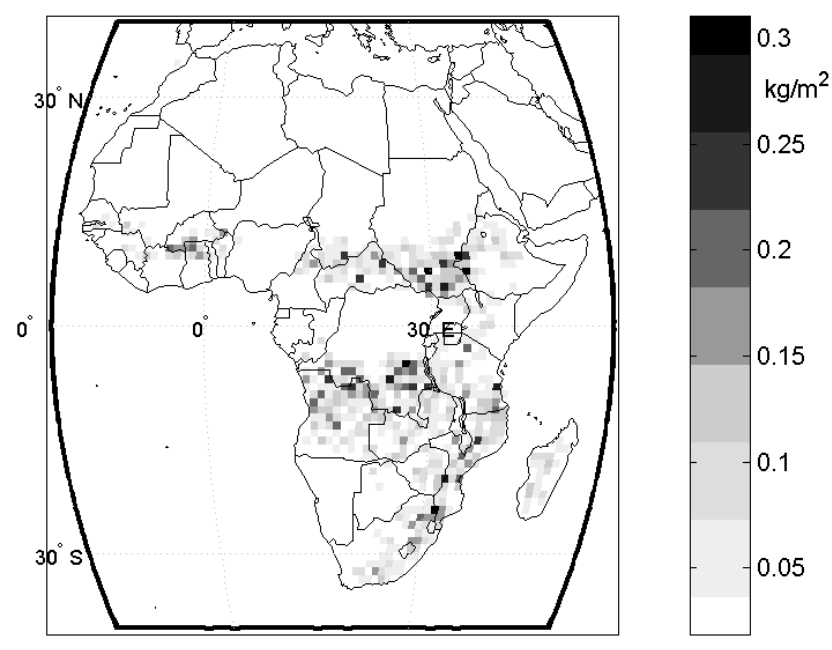

Fig. 5. Average pyrogenic annual $\mathrm{C}$ emissions by wildfires in $\mathrm{kg} \mathrm{C} \mathrm{m}^{-2} \mathrm{a}^{-1}$ for the period 2001 to 2006 simulated by LPJGUESS-SPITFIRE with burnt area prescribed from L3JRC.

2007), and 174 to $1200 \mathrm{Tg} \mathrm{Ca}^{-1}$ for SHA (Korontzi, 2005) suggested by other recent studies. Pyrogenic emissions are higher than the fossil fuel emissions from the African continent which were estimated to be on average $260 \mathrm{Tg} \mathrm{Ca}^{-1}$ between 2000 and 2005 by Canadell et al. (2008).

The vast majority of fires both for SHA and NHA were simulated to occur in the savannah biome. The total continental fire variability was (as expected) considerably smaller than the variability of both burned area and pyrogenic emissions of the savannah biome alone. This is an indication of a large dilution effect exerted by rainforest areas where only a very small proportion of the burned area for the whole continent was detected. 

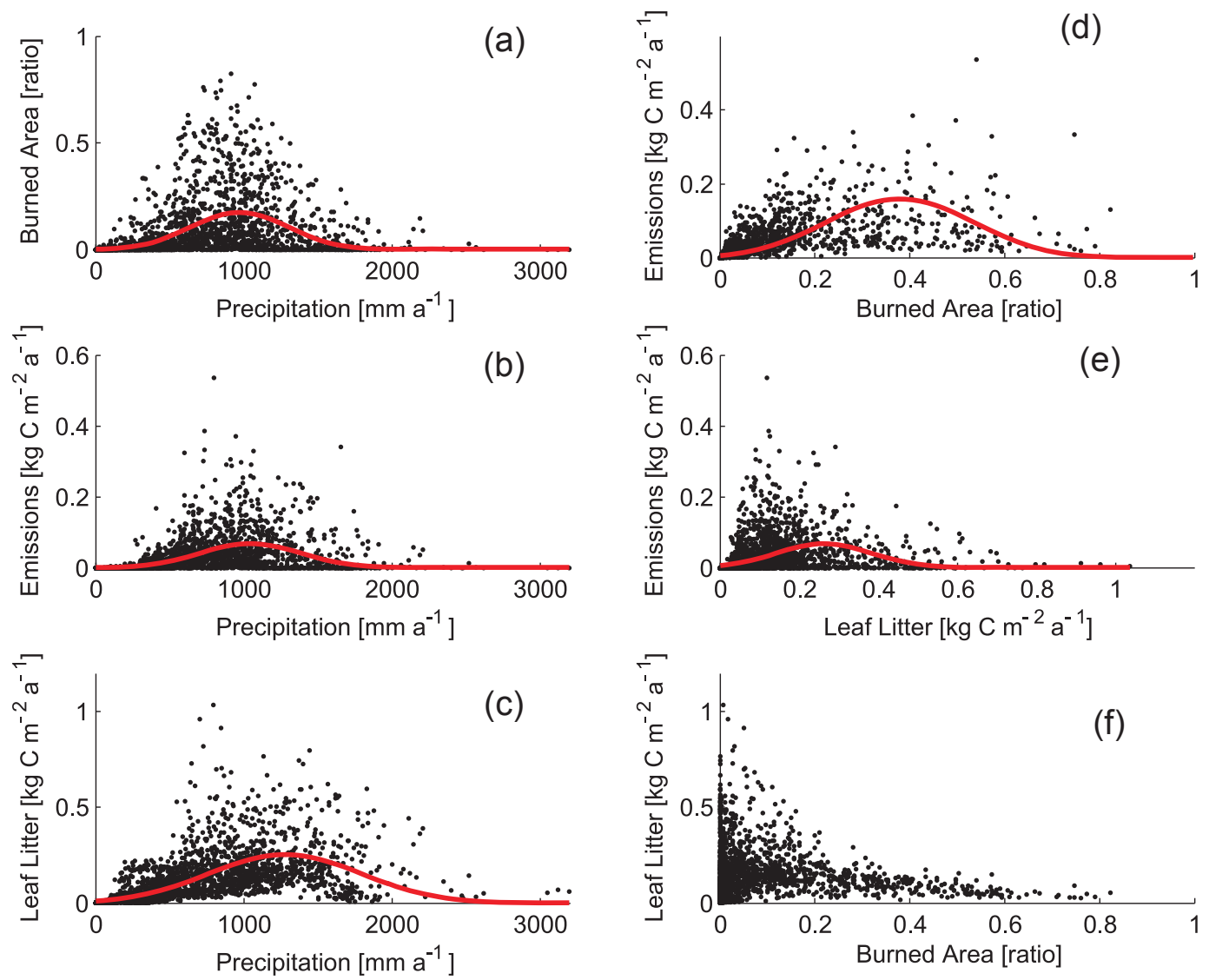

Fig. 6. The relationship between precipitation (prec), burned area (BA; expressed as fraction of a gridcell burnt), leaf litter (Lit) and emissions (E). Emission and burned area are scaled by dividing by $1 \mathrm{~kg} \mathrm{C}$ and $10 \mathrm{~kg} \mathrm{C}$ respectively for the estimation of the GLMs. All values are mean values for a 1-degree grid cell for 2000-2006. Coefficients of determination are given for each relationship, P-values for each parameter are below $10^{-10}$ in all cases (see Sect. 3.4 for further explanation). Red curves are fitted GLMs with the following parameters:

(a) $\operatorname{logit}(\mathrm{BA})=-0.0065+1.02 \cdot 10^{-5} \cdot \operatorname{Prec}-5 \cdot 27 \cdot 10^{-9} \cdot \operatorname{Prec}^{2}\left(r^{2}=0.51\right)$

(b) logit $(\mathrm{E})=-0.00347+0.145 \cdot \operatorname{Prec}-3.55 \cdot \operatorname{Prec}^{2}\left(r^{2}=0.51\right)$

(c) $\operatorname{logit}(\mathrm{Lit} / 10)=-0.0068+4.92 \cdot 10^{-6} \cdot \operatorname{Prec}-1.92 \cdot 10^{-9} \cdot \operatorname{Prec}^{2}\left(r^{2}=0.63\right)$

(d) $\operatorname{logit}(\mathrm{E})=-0.0051+0.018 \cdot \mathrm{BA}-0.024 \cdot \mathrm{BA}^{2}\left(r^{2}=0.66\right)$

(e) $\operatorname{logit}(\mathrm{E})=-0.00511+0.189 \cdot \mathrm{Lit} / 10-3.58 \cdot(\mathrm{Lit} / 10)^{2}\left(r^{2}=0.37\right)$.

In the comprehensive study of global biomass burning by van der Werf et al. (2006), the estimated pyrogenic emissions from SHA of $576 \pm 72 \mathrm{Tg} \mathrm{Ca}^{-1}$ were calculated for a burned area of $79.3 \pm 9.6 \times 10^{4} \mathrm{~km}^{2}$. These values are in the same range as an earlier estimate (van der Werf et al., 2003) based on the same biogeochemical model, but for a single year only and with different driving data. For NHA, $627 \pm 75 \mathrm{Tg} \mathrm{Ca}^{-1}$ were emitted from a burned area of $142.5 \pm 12.3 \times 10^{4} \mathrm{~km}^{2}$; excluding the Mediterranean regions. In a study by Scholes et al. (1996a), burned area and biomass estimates from remotely sensed NDVI and hot spot data were combined with a functional vegetation type classification with respect to the fire regime. Fuel load in this approach was estimated from mean annual precipita- tion and vegetation. Their estimate of biomass burned for SHA, 45-132 $\mathrm{C} \mathrm{a}^{-1}$ (90-264 Tg dry matter $\left.\mathrm{a}^{-1}\right)$ in the year 1989, is much lower than our estimate of between 379 and $580 \mathrm{Tg} \mathrm{Ca}^{-1}$ for the six-year period 2001-2006. While our estimates of the pyrogenic emissions and burnt area are comparable to the results from van der Werf et al. $(2003,2006)$ for SHA, they differ substantially for the northern part of the continent. Aside from differences in the calculated productivity (see below) this discrepancy might be explained by the proportionally larger burned area in NHA compared to SHA inferred by van der Werf (2006). L3JRC depicts a significantly lower burnt area in NHA than SHA even though the Mediterranean areas are included. Since L3JRC is based on the detection of burn scars, which remain visible for longer 
than an active fire, it should provide more accurate information than a hot spots product (Giglio et al., 2006; van der Werf et al., 2006). In some regions, burn scars are likely to be underestimated, but we applied corrections (Tansey et al., 2008b) to compensate for this.

Our approach estimates wildfire emissions based on observed climate and inferred fuel loads. An alternative approach is to use remotely-sensed fire radiative energy as a proxy for combustion completeness. In a recent study, Roberts et al. (2008) derived the annual African pyrogenic carbon emission to be above $427 \mathrm{Tg} \mathrm{C}$ (855 Tg dry mass) between February 2004 and January 2005. The authors consider this value to be an underestimate because in their analysis the majority of African fires are detected only once in consecutive 15 min imaging slots, suggesting a high number of undetected fires. Allowing for some underestimation, the Roberts et al. study provides some tentative support for our estimate of $718 \mathrm{TgC}$ for 2004 based on an independent method.

Interannual variability of fire-related carbon emissions (1985-1991) was reported in Barbosa et al. (1999) for Southern Hemisphere Africa, using images from the AVHRR sensor with a $5 \mathrm{~km}$ resolution combined with a map of the main vegetation classes. These classes were used to assign biomass density, combustion efficiency and emission factors to each biome which were modified by weekly values of NDVI, derived from the same remote sensing product. Their value of $50 \%$ was larger than the $34 \%$ calculated in our study. The differences in methodology as well as in the in time periods covered makes a direct comparison difficult. Overall, we consider our estimates of burned biomass and its inter-annual variability to be rather conservative owing to the use of precipitation at relatively coarse resolution (2.5 degree grid from NCEP, Kalaney 1996) which, combined with the assumption of homogenous precipitation throughout each grid cell, may lead to an underestimation of fuel dryness.

Variation in NPP affects fuel load and thus the amount of biomass that can be combusted and sustain fire spread. The total amount and distribution of NPP and the processes underlying its interannual variability in NPP constitute a major uncertainty in the estimation of African fire emissions. Using the CASA biogeochemical model constrained by remotely sensed NDVI, van der Werf et al. (2006) estimated an NPP of $13 \mathrm{Pg} \mathrm{Ca}^{-1}$ for the whole of Africa, which is at the upper end of published estimates, which range from 7 to $13 \mathrm{Pg} \mathrm{Ca}^{-1}$ (Williams et al., 2007). The lower NPP calculated with LPJ-GUESS, 9.0 $\mathrm{Pg} \mathrm{Ca}^{-1}$ as an average over the simulation period, is one of the reasons for the lower estimated continental emission of carbon in this study compared to van der Werf et al. (2006), even though the L3JRC burned area is larger than the hotspot-based burned area dataset used in the van der Werf study. On a burned area basis, van der Werf (2006) estimated emissions of $441 \mathrm{~g} \mathrm{C} \mathrm{m}^{-2} \mathrm{a}^{-1}$ for NHA and $734 \mathrm{~g} \mathrm{C} \mathrm{m}^{-2} \mathrm{a}^{-1}$ for SHA compared with our estimates of $318 \mathrm{~g} \mathrm{C} \mathrm{m}^{-2} \mathrm{a}^{-1}$ and $414 \mathrm{~g} \mathrm{C} \mathrm{m}^{-2} \mathrm{a}^{-1}$, respec- tively. Differences in NPP calculation between CASA and LPJ-GUESS are likely the main reason for these different estimates. Although both studies arrived at higher average pyrogenic emissions for SHA, their regional totals still differ by up to $70 \%$.

The uni-modal relationship emerging between burned area and precipitation for African savannahs is similar to the relationship between mean annual precipitation and the proportion of area burned for the wet-dry tropics of Northern Australia (Spessa et al., 2005). There, burned area peaked around $1200 \mathrm{~mm}$ annual precipitation, and mean proportion of burned area at this maximum was somewhat higher (0.28) compared with 0.2 in our study. These observations indicate a strong similarity in the functional properties of savannahs in different parts of the world. The common denominator is that precipitation is an important driver not only for NPP but also for litter production and thereby fuel load (Fig. 6c, $r^{2}=0.63$ ), as demonstrated also at the site level by Hély et al. (2007).

In our simulations, the relationship between leaf litter and emissions was relatively weak (Fig. 6e, $r^{2}=0.37$ ). Although this may seem counter-intuitive, two explanations can be offered: (i) wet regions also accumulate litter, but either do not burn as frequently as expected from their fuel load alone, or if they burn, their lower combustion efficiency results in low emission rates per litter combusted; (ii) frequently burned areas (Fig. 6f) tend to have low fuel loads, because a certain amount of time is needed for litter to accumulate. In our modelled results, emissions decline for burned areas that are proportionally larger than 0.4 (Fig. 6b). However, combining burned area and available litter in a GLM resulted in a higher coefficient of determination than using burned area as the sole predictor of carbon emissions, indicating the importance of both factors for emissions.

Emissions of wildfires have been successfully related to large scale phenomena such as the El Niño Southern Oscillation (ENSO) and the Indian Ocean Dipol Oscillation (Riaño et al., 2007; Patra et al., 2005). Biomass burning has been shown to strongly contribute to inferred $\mathrm{CO}_{2}$ flux anomalies in tropical regions (Patra et al., 2005). In an analysis of an 18-year time series of burned area data, Riaño et al. (2007) found the Southern Oscillation Index to be a statistically significant predictor variable of African burned area with a time lag of 20 months. In our study, neither an extreme El Niño nor an extreme La Niña event occurred over the observation period i.e. the Oceanic Niño Index (ONI) was in the range of -1.7 and +1.5 ( 3 month running average) compared to the strong El Niño event 1997 that resulted in maximum ONI values $^{3}$ of 2.5. While the absence of a strong El Niño event in the study period precludes us to add to the related body of literatures it may well serve as an indication that the annual variation in NPP as well as burnt area at least in some

\footnotetext{
${ }^{3}$ Data from http://www.cpc.ncep.noaa.gov/products/analysis/ monitoring/ensostuff/ensoyears.shtml.
} 
regions of the African continent might be larger compared to the results presented here.

The vast majority of fires in Africa are ignited by humans (Saarnak, 2001) as part of grazing management and agricultural activities. SPITFIRE distinguishes anthropogenic and lightning ignition sources to calculate burnt area, but both are complex to parameterise and will be investigated in a separate study (Lehsten et al., unpublished). Using a global parameterisation of ignitions by humans, Thonicke et al. (2008) calculate a burnt area of $117 \pm 14 \times 10^{4} \mathrm{~km}^{2}$ in NHA and $198 \pm 18 \times 10^{4} \mathrm{~km}^{2}$ in SHA (mean value for 1997-2002 \pm standard deviation), somewhat larger than L3JRC, but with a similarly greater burned area south of the equator. While not part of the analysis here, adopting a suitable parameterisation for human caused ignition patterns based on population distribution and life-style is an important task to reduce uncertainties in the modelling of African fires (Archibald et al., 2009).

The calculated emissions are influenced by errors in all parts of the simulation as well as errors propagating from the remote sensing and climate data. Since LPJ-GUESS and SPITFIRE interact very strongly in the simulation of different processes and at different timescales, a rigorous error propagation analysis would be challenging, and well beyond the scope of the present study. However, we here attempt to highlight the main uncertainties in the modelling. The sensitivity of LPJ-GUESS and the closely-related global model LPJ-DGVM to its many parameters was explored by Zaehle et al. (2005) and Wramneby et al. (2008). Zaehle et al. showed that the modelled NPP responds strongly to the settings of parameters governing the quantum efficiency of photosynthesis and the efficiency with incoming solar radiation is absorbed by leaves. Both parameters are rather uncertain and vary among species, biomes, climate zones and the seasons. Despite such uncertainty, the overall modelled carbon cycle response to trends in climate or atmospheric $\mathrm{CO}_{2}$ concentrations show robust features and agreement with observations such as ecosystem carbon fluxes (Zaehle et al., 2005; Wramneby et al., 2008). For the simulation of global burned biomass with LPJ-SPITFIRE, Thonicke et al. (2008) found that uncertainties in fuel bulk density (FBD) and population density affected the results most substantially. Population density affects ignition but is irrelevant in our study as burnt area was prescribed. FBD directly influences fire spread as well as overall combustion and hence vegetation mortality. For the global simulations, biomass burning using maximum published values for FBD differed by $57 \%$ from simulations that used the lowest published FBD values (Thonicke et al., 2008). We expect our simulation to be less sensitive to the uncertainty in FBD because our approach to prescribe burned area from a satellite product eliminates the influence of FBD on burned area. Nonetheless, the uncertainty in the L3JRC database may be of the same order of magnitude even though a correction by land cover class has been performed.

\section{Outlook}

Using a novel approach, our estimates of burnt area and biomass for sub-Saharan Africa are within the range of previous estimates. Using a dynamic vegetation model allowed us to characterise the strongly non-linear relationships among precipitation, NPP and litter production as the main drivers of fire emissions, yielding some general patterns that might be representative for savannah ecosystems globally.

Projected climate change in Africa is expected to result in a decrease in continental NPP as declining precipitation in savannah areas stresses plants (Friedlingstein et al., 2008), counteracting the effects of $\mathrm{CO}_{2}$ fertilisation (Hickler et al., 2008). Our results confirm the dependence of burned area and pyrogenic carbon emissions on precipitation, and we may therefore expect the fire regime to be strongly influenced by reducing rainfall trends. Though wildfires per se do not generate a net $\mathrm{CO}_{2}$ flux to the atmosphere as long as the vegetation can sequester the carbon by subsequent growth, a change in precipitation as well as a change in fire regime can change the carbon stocks in the biomass as well as in the soil and thereby result in a net loss of $\mathrm{CO}_{2}$ to the atmosphere. Wildfires have been shown to depend crucially on socio-economic drivers (Archibald et al., 2008). Studies developing global change projections as well as past pattern of African fire emissions will need to develop methods to account for human and natural (lightning) ignition patterns and to simulate ignition dynamically instead of using a prescribed burned area.

Acknowledgements. The work was supported by the European Commission via the FP6 project CarboAfrica. We thank Bashir Awad El Tahir for providing the vegetation parameters for savannah trees. The L3JRC production team, J.-M. Grégoire, P. Defourny, R. Leigh, J.-F. Pekel, E. van Bogaert, E. Bartholomé, J. M. C. Pereira, A. Barros and J. Silva are acknowledged. C. Prentice contributed to the development of the SPITFIRE model. P. Harmand's help with statistical issues is acknowledged.

Edited by: J. Kesselmeier

\section{References}

Archibald, S., Roy, D. P., van Wilgen, B. W., and Scholes, R. J.: What limits fire?: An examination of drivers of burnt area in Southern Africa, Glob. Change Biol., 15(3), 613-630, 2008.

Barbosa, P. M., Stroppiana, D., Grégoire, J. M., and Pereira, J. M. C.: An assessment of vegetation fire in Africa (19811991): Burned areas, burned biomass, and atmospheric emissions, Global Biogeochem. Cy., 13, 933-950, 1999.

Byram, G. M.: Combustion of forest fuels, in: Forest Fire: Control and Use, edited by: Davis, K., McGraw-Hill Book Company, New York, 61-89, 1959.

Canadell, J. G., Raupach, M. R., and Houghton, R. A.: Anthropogenic $\mathrm{CO}_{2}$ emissions in Africa, Biogeosciences Discuss., 5, 4395-4411, 2008, http://www.biogeosciences-discuss.net/5/4395/2008/. 
Dobson, A. J.: An introduction to generalized linear models, Chapman \& Hall/CRC texts in statistical science series, Chapman \& Hall/CRC, Boca Raton, Chapter 2, 2002.

Friedlingstein, P., Cadule, P., Piao, S. L., Ciais, P., and Sitch, S.: The African contribution to the global climate-carbon cycle feedback of the 21st century, Biogeosciences Discuss., 5, 4847-4866, 2008, http://www.biogeosciences-discuss.net/5/4847/2008/.

Gerten, D., Schaphoff, S., Haberlandt, W., Lucht, W., and Sitch, S.: Terrestrial vegetation and water balance - hydrological evaluation of a dynamic global vegetation model, J. Hydrol., 286, 249-270, 2004.

Giglio, L., van der Werf, G. R., Randerson, J. T., Collatz, G. J., and Kasibhatla, P.: Global estimation of burned area using MODIS active fire observations, Atmos. Chem. Phys., 6, 957-974, 2006, http://www.atmos-chem-phys.net/6/957/2006/.

Hanan, N. P., Sea, W. B., Dangelmayr, G., and Govender, N.: Do fires in savannas consume woody biomass? A comment on approaches to modeling savanna dynamics, Am. Nat., 171, 851856, 2008.

Haxeltine, A. and Prentice, I. C.: A general model for the light-use efficiency of primary production, Funct. Ecol., 551-561, 1996.

Hély, C., Caylor, K. K., Dowty, P., Alleaume, S., Swap, R. J., Shugart, H. H., and Justice, C. O.: A temporally explicit production efficiency model for fuel load allocation in southern Africa, Ecosystems, 10, 1116-1132, 2007.

Hickler, T., Prentice, I. C., Smith, B., Sykes, M. T., and Zaehle, S.: Implementing plant hydraulic architecture within the LPJ Dynamic Global Vegetation Model, Global Ecol. Biogeogr., 15, 567-577, 2006.

Hickler, T., Smith, B., Prentice, I. C., Mjöfors, K., Miller, P., Arneth, A., and Sykes, $\mathrm{M}$.: $\mathrm{CO}_{2}$ fertilization in temperate FACE experiments not representative of boreal and tropical forests, Glob. Change Biol., 14, 1-12, 2008.

Huntingford, C. and Monteith, J. L.: The behaviour of a mixedlayer model of the convective boundary layer coupled to a big leaf model of surface energy partitioning, Bound.-Lay. Meteorol., 88, 87-101, 1998.

Kalnay, E., Kanamitsu, M., Kistler, R., Collins, W., Deaven, D., Gandin, L., Iredell, M., Saha, S., White, G., Woollen, J., Zhu, Y., Chelliah, M., Ebisuzaki, W., Higgins, W., Janowiak, J., Mo, K. C., Ropelewski, C., Wang, J., Leetmaa, A., and Reynolds, R.: The NCEP/NCAR 40-year 30 reanalysis project, B. Am. Meteorol. Soc., 77, 437-470, 1996.

Kasischke, E. S., Hewson, J. H., Stocks, B., van der Werf, G., and Randerson, J.: The use of ATSR active fire counts for estimating relative patterns of biomass burning - a study from the boreal forest region, Geophys. Res. Lett., 30(4), 1969, doi:10.1029/2003GL017859, 2003.

Korontzi, S.: Seasonal patterns in biomass burning emissions from southern African vegetation fires for the year 2000, Glob. Change Biol., 11, 1680-1700, 2005.

Kummerow, C., Barnes, W., Kozu, T., Shiue, J., and Simpson, J.: The Tropical Rainfall Measuring Mission (TRMM) sensor package, J. Atmos. Ocean. Tech., 15, 809-817, 1998.

Lehsten, V., Arneth, A., Thonicke, K., Spessa, A., and Prentice, I.-C.: Tree-Grass coexistence in Savannahs: testing two mechanisms, Global Ecol. Biogeogr., in preparation, 2009.

Miller, P. A., Giesecke, T., Hickler, T., Bradshaw, R. H. W., Smith, B., Seppa, H., Valdes, P. J., and Sykes, M. T.: Exploring climatic and biotic controls on Holocene vegetation change in Fennoscandia, J. Ecol., 96, 247-259, 2008.

Mitchell, T. D. and Jones, P. D.: An improved method of constructing a database of monthly climate observations and associated high-resolution grids, Int. J. Climatol., 25, 693-712, 2005.

Nesterov, V. G.: Gorimost' lesa i metody eio opredelenia., Goslesbumaga, 75 pp., 1949.

Peterson, D. L. and Ryan, K. C.: Modeling Postfire Conifer Mortality for Long-range Planning, Environ. Manage., 10, 797-808, 1986.

Patra, P. K., Ishizawa, M., Maksyutov, S., Nakazawa, T., and Inoue, G.: Role of biomass burning and climate anomalies for land-atmosphere carbon fluxes based on inverse modeling of atmospheric $\mathrm{CO}_{2}$, Global Biogeochem. Cy., 19, GB3005, doi:10.1029/2004GB002258, 2005.

Pyne, S. J., Andrews, P. L., and Laven, R. D.: Introduction to wildland fire, Wiley, New York, 769 pp., 1996.

Riaño, D., Ruiz, J. A. M., Martinez, J. B., and Ustin, S. L.: Burned area forecasting using past burned area records and Southern Oscillation Index for tropical Africa (1981-1999), Remote Sens. Environ., 107(4), 571-581, 2007.

Roberts, G., Wooster, M. J., and Lagoudakis, E.: Annual and diurnal African biomass burning temporal dynamics, Biogeosciences Discuss., 5, 3623-3663, 2008, http://www.biogeosciences-discuss.net/5/3623/2008/.

Rothermel, R. C.: A Mathematical Model for Predicting Fire Spread in Wildland Fuels, Ogden, Utah, 30 pp., 1972.

Running, S. W., Ramakrishna, R. N., and Hungerford, R. D.: Extrapolation of synoptic meteorological data in mountainous terrain and its use for simulating forest evapotranspiration and photosynthesis, Can. J. Forest Res., 17, 472-483, 1987.

Saarnak, C. F.: A shift from natural to human-driven fire regime: implications for trace-gas emissions, Holocene, 11, 373-375, 2001.

Sankaran, M., Ratnam, J., and Hanan, N. P.: Tree-grass coexistence in savannas revisited - insights from an examination of assumptions and mechanisms invoked in existing models, Ecol. Lett., 7, 480-490, 2004.

Scholes, R. J., Kendall, J., and Justice, C. O.: The quantity of biomass burned in southern Africa, J. Geophys. Res.-Atmos., 101, 23667-23676, 1996a.

Scholes, R. J., Ward, D. E., and Justice, C. O.: Emissions of trace gases and aerosol particles due to vegetation burning in southern hemisphere Africa, J. Geophys. Res.-Atmos., 101, $23677-$ 23682, 1996b.

Simon, M., Plummer, S., Fierens, F., Hoelzemann, J. J., and Arino, O.: Burnt area detection at global scale using ATSR-2: The GLOBSCAR products and their qualification, J. Geophys. Res.Atmos., 109, D14S02, doi:10.1029/2003JD003622, 2004.

Sitch, S., Smith, B., Prentice, I. C., Arneth, A., Bondeau, A., Cramer, W., Kaplan, J. O., Levis, S., Lucht, W., Sykes, M. T., Thonicke, K., and Venevsky, S.: Evaluation of ecosystem dynamics, plant geography and terrestrial carbon cycling in the LPJ dynamic global vegetation model, Glob. Change Biol., 9, 161185, 2003.

Smith, B., Prentice, I. C., and Sykes, M. T.: Representation of vegetation dynamics in the modelling of terrestrial ecosystems: comparing two contrasting approaches within European climate space, Global Ecol. Biogeogr., 10, 621-637, 2001. 
Smith, R., Adams, M., Maier, S., Craig, R., Kristina, A., and Maling, I.: Estimating the area of stubble burning from the number of active fires detected by satellite, Remote Sens. Environ., 109, 95-106, 2007.

Spessa, A., McBeth, B., and Prentice, C.: Relationships among fire frequency, rainfall and vegetation patterns in the wet-dry tropics of northern Australia: an analysis based on NOAA-AVHRR data, Global Ecol. Biogeogr., 14, 439-454, 2005.

Tansey, K., Grégoire, J. M., Binaghi, E., Boschetti, L., Brivio, P. A., Ershov, D., Flasse, S., Fraser, R., Graetz, D., Maggi, M., Peduzzi, P., Pereira, J., Silva, J., Sousa, A., and Stroppiana, D.: A global inventory of burned areas at $1 \mathrm{~km}$ resolution for the year 2000 derived from SPOT VEGETATION data, Climatic Change, 67, 345-377, 2004.

Tansey, K., Beston, J., Hoscilo, A., Page, S. E., and Paredes Hernández, C. U.: Relationship between MODIS fire hot spot count and burned area in a degraded tropical peat swamp forest in Central Kalimantan, Indonesia, J. Geophys. Res., 113, D23112, doi:10.1029/2008JD010717, 2008a.

Tansey, K., Grégoire, J. M., Defourny, P., Leigh, R., Pekel, J. F. O., van Bogaert, E., and Bartholomé, E.: A new, global, multi-annual (2000-2007) burnt area product at $1 \mathrm{~km}$ resolution, Geophys. Res. Lett., 35, L01401, doi:10.1029/2007GL031567, 2008 b.

Thonicke, K., Spessa, A., Prentice, C., Harrison, S. P., and Carmona-Moreno, C.: The influence of vegetation, fire spread and fire behaviour on global biomass burning and trace gas emissions, submitted, 2008.

van der Werf, G. R., Randerson, J. T., Collatz, G. J., and Giglio, L.: Carbon emissions from fires in tropical and subtropical ecosystems, Glob. Change Biol., 9, 547-562, 2003. van der Werf, G. R., Randerson, J. T., Giglio, L., Collatz, G. J., Kasibhatla, P. S., and Arellano Jr., A. F.: Interannual variability in global biomass burning emissions from 1997 to 2004, Atmos. Chem. Phys., 6, 3423-3441, 2006, http://www.atmos-chem-phys.net/6/3423/2006/.

Venevsky, S., Thonicke, K., Sitch, S., and Cramer, W.: Simulating fire regimes in human-dominated ecosystems: Iberian Peninsula case study, Glob. Change Biol., 8, 984-998, 2002.

Weber, U., Jung, M., Reichstein, M., Beer, C., Braakhekke, M., Lehsten, V., Ghent, D., Kaduk, J., Viovy, N., Ciais, P., Gobron, N., and Rödenbeck, C.: The inter-annual variability of Africa's ecosystem productivity: a multi-model analysis, Biogeosciences Discuss., 5, 4035-4069, 2008, http://www.biogeosciences-discuss.net/5/4035/2008/.

Williams, C. A., Hanan, N. P., Neff, J. C., Scholes, R. J., Berry, J. A., Denning, A. S., and Baker, D. F.: Africa and the global carbon cycle, Carbon Bal. Manag., 2(3), 13 pp., 2007.

Williams, R. J., Gill, A. M., and Moore, P. H. R.: Seasonal Changes in Fire Behaviour in a Tropical Savanna in Northern Australia, Int. J. Wildland Fire, 8, 227-239, 1998.

Wilson, R. A. J.: A re-examination of fire spread in free burning porous fuel beds, Intermountain Forest and Range Experiment Station, Forest Service, US Dept. of Agriculture, Ogden, Utah, 1982.

Wramneby, A., Smith, B., Zaehle, S., and Sykes, M. T.: Parameter uncertainties in the modelling of vegetation dynamics - Effects on tree community structure and ecosystem functioning in European forest biomes, Ecol. Model., 216(3-4), 277-290, 2008.

Zaehle, S., Sitch S., Smith, B., and Hatterman, F.: Effects of parameter uncertainties on the modeling of terrestrial biosphere dynamics, Global Biogeochem. Cy., 19(3), GB3020, doi:10.1029/2004GB002395 2005. 